\title{
DRUG RESISTANCE IN HELICOBACTER PYLORI
}

\author{
Júlia Silveira VIANNA ${ }^{1,2}$, Ivy Bastos RAMIS ${ }^{2}$, Daniela Fernandes RAMOS ${ }^{2}$, \\ Andrea VON GROLL ${ }^{2}$ and Pedro Eduardo Almeida da SILVA ${ }^{2}$
}

Received 2/3/2016

Accepted 7/6/2016

ABSTRACT - Background - Helicobacter pylori has a worldwide distribution and is associated with the pathogenesis of various diseases of the digestive system. Treatment to eradicate this microorganism involves the use of a combination of antimicrobials, such as amoxicillin, metronidazole, clarithromycin, and levofloxacin, combined with proton pump inhibitors. Although the current therapy is effective, a high rate of treatment failure has been observed, mainly because of the acquisition of point mutations, one of the major resistance mechanisms developed by $H$. pylori. This phenomenon is related to frequent and/or inappropriate use of antibiotics. Conclusion - This review reported an overview of the resistance to the main drugs used in the treatment of H. pylori, confirming the hypothesis that antibacterial resistance is a highly local phenomenon and genetic characteristics of a given population can influence which therapy is the most appropriate.

HEADINGS - Helicobacter pylori. Microbial drug resistance. Point mutation.

\section{INTRODUCTION}

Helicobacter pylori is a spiral, Gram-negative bacteria that is linked with the pathogenesis of several diseases of the digestive system ${ }^{(107)}$. Infection caused by H. pylori in the gastric mucosa is associated with inflammatory processes, resulting in gastritis, peptic ulcer disease, and neoplastic processes, as well as adenocarcinoma and mucosal-associated lymphoid tissue (MALT) ${ }^{(19)}$.

Although $H$. pylori infection has a worldwide distribution, its prevalence has been decreasing in some regions ${ }^{(39,60)}$. However, the wide-scale prevention of the spread of this bacteria has not yet been achieved, mainly due to the high failure rates of the eradication therapeutics that are available that have been observed in many regions of the world. In the last 5 years, studies have highlighted variations in the rates of resistance of the main antibiotics used to eradicate

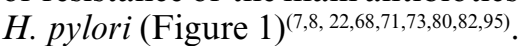

The use of triple therapy to treat H. pylori infection, which consists of proton pump inhibitors, clarithromycin, and amoxicillin or metronidazole, has become universal; however, the most recent data indicates that this combination of treatments has lost efficacy and is now only effective in a maximum of $70 \%$ of patients. In areas of high clarithromycin resistance, bismuth-containing quadruple treatments are recommended for first-line empiric treatment. The other alternative is a second-line treatment based on proton pump inhibitors, levofloxacin, and amoxicillin ${ }^{(53)}$.

Specific SNP (single nucleotide polymorphisms) are the main molecular basis of drug resistance in $H$. pylori infections and the pressure that determines the selection of resistant strains is related to frequent and/ or inappropriate use of antibiotics ${ }^{(11,34,79)}$.

In the event that second-line treatment fails, antimicrobial susceptibility testing should be performed prior to any further treatment ${ }^{(53)}$. While phenotypic methods represent the gold standard for drug susceptibility tests, $H$. pylori is a fastidious microorganism that is difficult to detect through the phenotypic approach; as such, drug resistance can be determined using molecular methods ${ }^{(55)}$. This review examines current knowledge about the drug resistance of $H$. pylori.

\section{RESISTANCE MECHANISMS OF H. PYLORI}

Bacteria's ability to adapt and become resistant to antibiotics has made it increasingly difficult to treat many bacterial infections. This has proven to be the case with the gastric pathogen H. pylori. H. pylori is associated with diseases such as gastritis, peptic ulcers,

${ }_{1}^{1}$ Programa de Pós-Graduação em Biotecnologia, Universidade Federal de Pelotas, RS, Brasil; ${ }^{2}$ Núcleo de Pesquisas em Microbiologia Médica, Universidade Federal do Rio Grande, RS, Brasil.

Correspondence: Júlia Silveira Vianna. Núcleo de Pesquisas em Microbiologia Médica, Universidade Federal do Rio Grande. Rua General Osório, s/n, Rio Grande, RS Brasil. E-mail: jusvianna@hotmail.com 


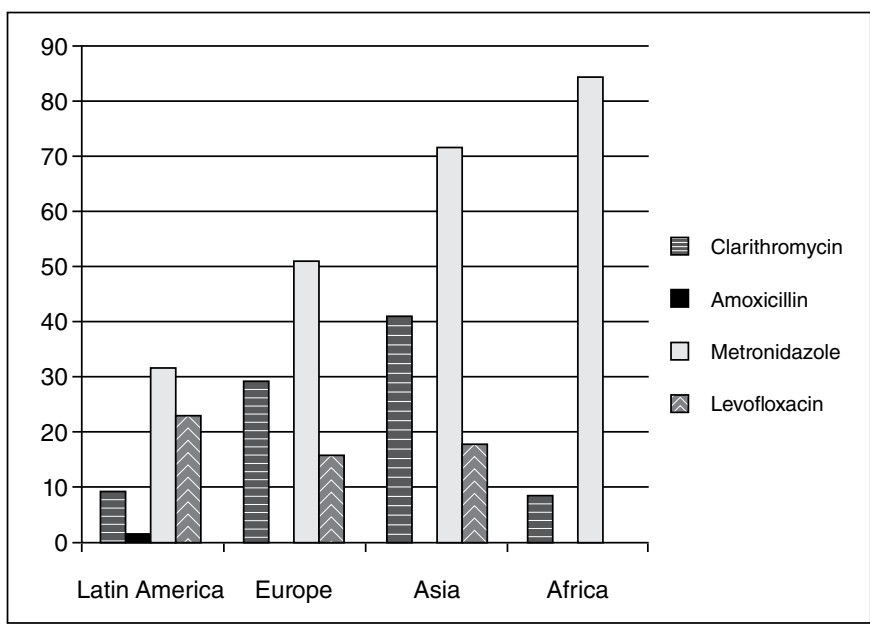

FIGURE 1. Geographic distribution of the mean between the resistance rates to the main antibiotics used to treat $H$. pylori in the last 5 years (2010-2015).

and carcinoma. The molecular basis of drug resistance in $H$. pylori has been found to result from the drug efflux mechanism or can be attributed to the presence of mutations ${ }^{(55)}$.

Drug efflux results from the action of a transporter protein that may result from a reduction of the antimicrobial concentration inside of a bacterial cell, increasing its chances of surviving in the presence of antimicrobials. Three pumps of the RND family (hefC, hefF, hefI), have been shown to be involved in multidrug efflux, including clarithromycin ${ }^{(45)}$. Furthermore, recent research has demonstrated that the overexpression of hef $A$ pump may be related to the initial step in the bacteria's acquisition of resistance to the metronidazole in $H$. pylori $i^{(101)}$. However, the main $H$. pylori resistance mechanism results from the acquisition of point mutations. With regard to clarithromycin, the mutation mechanism is mainly in the $23 S$ rRNA region, while the amoxicillin resistance acquisition is associated with mutation in the penicillin binding proteins (PBPs), and metronidazole and levofloxacin are associated with a mutation in the $r d x A$ and $g y r A$ genes respectively ${ }^{(21,30,104,106)}$. $H$. pylori's resistance to the main drugs used in therapy have been frequently evaluated; however, in countries like Brazil, studies that have examined the association between the presence of point mutations and resistance to $H$. pylori are often restricted to clarithromycin.

\section{METHODS FOR DETECTING RESISTANCE}

In routine clinical microbiology, the detection of susceptibility to antibiotics is mainly based on phenotypic methods. However, H. pylori has slow growth and requires specific culture medium, making this phenotypic approach challenging and slow. Allied to this, due to the fact that the main antimicrobial resistance mechanism is often associated with point mutations, studies have proposed the implementation of a molecular approach from gastric biopsy specimens of H. pylori in clinical practice ${ }^{(12,16,55,90)}$.
Relationships between phenotypic and PCR methods have shown an excellent concordance for the detection of resistance to clarithromycin, as can be seen in Table $1^{(1,2,12,26,47,49,52,72)}$. These data show the validity of using molecular methods in clinical practice, as well as these tests detect resistance and allow the definition of the molecular basis related to it, also outweigh delays the laborious $H$. pylori culture.

TABLE 1. Comparation of the results of studies between phenotypic and genotypic method for determining resistance clarithromycin

\begin{tabular}{lccccc}
\hline Region & $\begin{array}{c}\text { Phenotypic } \\
(\mathbf{n})\end{array}$ & $\begin{array}{c}\text { Genotypic } \\
(\mathbf{n})\end{array}$ & $\begin{array}{c}\text { Agreement } \\
\text { between the } \\
\text { two methods }\end{array}$ & $\begin{array}{c}\text { Kappa } \\
\text { index }\end{array}$ & Reference \\
\hline Brazil & $20 / 202$ & $18 / 202$ & $90 \%$ & $0.94 *$ & Magalhães et al. ${ }^{(52)}$ \\
Brazil & $12 / 45$ & $12 / 45$ & $100 \%$ & $1 *$ & Garcia et al. $^{(27)}$ \\
Brazil & $24 / 114$ & $27 / 114$ & $97 \%$ & $0.92 *$ & Lins et al. $^{(49)}$ \\
Spain & $42 / 118$ & $34 / 118$ & $81 \%$ & $0.84 *$ & Agudo et al. $^{(2)}$ \\
France & $24 / 229$ & $24 / 229$ & $100 \%$ & $1 *$ & Burucoa et al. $^{(12)}$ \\
France & $10 / 59$ & $11 / 59$ & $98 \%$ & $0.94 *$ & Lascols et al. ${ }^{(47)}$ \\
Iran & $32 / 147$ & $31 / 147$ & $97 \%$ & $0.98 *$ & Abadi et al. ${ }^{(1)}$ \\
\hline * & & & & &
\end{tabular}

Some studies have used molecular assays, such as PCRRFLP, to detect $H$. pylori infection and to identify the specific mutations in the $23 S$ rRNA sequence that confer resistance to clarithromycin, which is the antibiotic of first choice in the treatment of $H$. pylori ${ }^{(56)}$. This technique has been proven to be simple, fast and accurate to execute. As such, it has the potential to overcome the delays associated with conventional culture method and, therefore, may be useful for routine practice ${ }^{(3,16,91)}$. Data in the literature has shown that mutations in the $23 S$ rRNA of $H$. pylori seem to be more suitable resistance markers for the purposes of predicting treatment outcomes than phenotypic analysis ${ }^{(51)}$.

The PCR-RFLP technique has also been well documented in molecular typing of $H$. pylori strains that affect subjects before and after treatment for eradication of this bacteria, which makes this fundamental detection type ${ }^{(25,35)}$. The reappearance of $H$. pylori in a previously treated patient can occur through two distinct mechanisms: recrudescence and re-infection. Recrudescence involves the reappearance of the original $H$. pylori strain after its temporary suppression, indicating that it was not effectively eradicated, while reinfection occurs when, after successful eradication, a patient is infected with a new strain of $H$. pylori ${ }^{(15)}$. It is possible to differentiate between re-infection and the recurrence of $H$. pylori strains in patients after a standard triple therapy using PCR-RFLP of a fragment of the ure $C$ gene. This method is considered to be fast, effective and useful for epidemiological studies of $H$. pylori infections and for monitoring patients before and after eradication therapy ${ }^{(25,35,48,59,63,87,88)}$. 


\section{DRUGS USED IN ANTI-H. PYLORI THERAPY}

\section{Clarithromycin}

Clarithromycin is a drug of the macrolide family that is used as an essential component of standard triple therapy for H. pylori ${ }^{(18)}$. However, the successful treatment of $H$. pylori in regimes containing this antibiotic is declining, and this phenomenon can be caused by prolonged use of clarithromycin to treat other infectious diseases, which favors the emergence of resistant microorganisms due to the development a selection pressure ${ }^{(93)}$. The main mechanism of action of the macrolides is to inhibit protein synthesis-dependent RNA by binding to receptors located in the $50 \mathrm{~S}$ ribosome, especially in the $23 S \mathrm{rRNA}$, the region in which the main resistance mutations associated with $H$. pylori clarithromycin are located ${ }^{(104)}$.

According to the increase in resistance rates over time, we can classify resistance according to three categories. "Primary", in which resistance is linked to previous exposure to the antibiotic for the treatment of other infections unrelated to H. pylori, such as respiratory tract infections; "secondary", resulting from a previous infection of $H$. pylori, and "tertiary" resistance, which is related to more than one episode ${ }^{(108)}$.

In Europe, an increase in resistance to this macrolide has been observed. Between 2005 and 2012 in Germany, the rates of primary, secondary and tertiary resistance were recorded as $7.5 \%, 63.2 \%$ and $75.4 \%$, respectively ${ }^{(83)}$. While in France, the primary and secondary resistance rates were observed at $18.6 \%$ and $41.6 \%$ from $1993-1996$ and 2001-2004 respectively. This increase in resistance confirms that prior treatment with clarithromycin increases the chances that an individual will acquire resistance to this antibiotic. In addition, the rates of the primary resistance have remained high in some European countries, like Poland and Italy, with rates of $24 \%$ and $35 \%$ respectively ${ }^{(7,74,80)}$.

Likewise, in Japan, a study that evaluated a total of 3,307 clinical isolates of $H$. pylori observed an increase in the levels of resistance over time, from $18.9 \%$ (2002 to 2003) to $27.7 \%$ (2004 to 2005). Another study in Japan evaluated 750 patients undergoing first-line therapy eradication, and found that primary resistance to clarithromycin increased significantly from $8.7 \%$ between 1997 and 2000 to $34.5 \%$ between 2007 and 2008. In addition, the eradication rate decreased significantly from $90.6 \%$ to $74.8 \%$. These studies suggest the need for monitoring the resistance and development of new therapeutic regimes for the first-line eradication of $H$. pylori ${ }^{(43,81)}$. On the other hand, a large geographic variation has been observed, and an uneven distribution is possible, even within the confines of a single country, since low resistance rates have also been detected in $\mathrm{Asia}^{(112)}$. In Taiwan, with a resistance rate of $6.6 \%$, it is indicated the use of clarithromycin as part of $H$. pylori routine treatment in this Asian population ${ }^{(109)}$.

Similarly, studies have observed low resistance rates of $H$. pylori to clarithromycin in Africa and also in Latin America in countries such as Paraguay $(2.2 \%)$ and Colombia $(3.8 \%)^{(3,23,82,95)}$. However, in a meta-analysis of Latin American populations, the summary prevalence of primary and secondary resistance was $12 \%{ }^{(14)}$. In Brazil, the use of clarithromycin has been considered a good option for the treatment of first-line antiH. pylori ${ }^{(22,71)}$. However, between 2000 and 2014, the rates of primary resistance ranged from $7 \%$ to $27 \%$ in Southern and South-Eastern areas of Brazil, while a rate of $16.5 \%$ was observed in the North-Eastern area (Table 2) $22,26,28,49,52,57,71,75)$. These variations in resistance rates reinforced the observations of Sierra et al. (2013), who argued that the therapeutic order should be carried out in accordance with local antimicrobial resistance studies; therefore, clarithromycin should be prescribed cautiously and, when possible, after susceptible drug determination ${ }^{(84)}$.

The increasing use of clarithromycin to treat several infectious diseases may have resulted in the development of selected resistant $H$. pylori strains and the main mutations that occur in $23 S \mathrm{rRNA}$ region, especially in A2143G, $\mathrm{A} 2142 \mathrm{G}$, and $\mathrm{A} 2142 \mathrm{C}^{(52,58,65,104)}$. Additional mutations have also been observed in the $\mathrm{V}$ region of the $23 S$ rRNA gene, including $\mathrm{T} 2182 \mathrm{C}^{(40)}, \mathrm{G} 2224 \mathrm{~A}^{(32)}$, and $\mathrm{T} 2215 \mathrm{C}^{(86)}$.

In particular, the $\mathrm{A} 2143 \mathrm{G}$ mutation has an impact on the assignment of global resistance. European countries show the $\mathrm{A} 2143 \mathrm{G}$ mutation predominantly in strains resistant to clarithromycin, with rates of $85.0 \%$ and $90.0 \%$ in Spain and France respectively ${ }^{(2,74)}$. In Poland, Klesiewicz et al. (2014) found the same frequency of $\mathrm{A} 2143 \mathrm{G}$ and $\mathrm{A} 2142 \mathrm{G}$ mutation in all tested samples; however, the $\mathrm{A} 2143 \mathrm{G}$ point mutation was correlated with a low level of phenotypic resistance to clarithromycin in comparison to the A2142G mutation ${ }^{(42)}$. In Spain, the T2182C mutation, also described in the $\mathrm{V}$ region of the $23 S$ rRNA gene, was detected; however, less often $(5.9 \%)$ than the A2143G mutation (85.3\%) among the strains resistant to clarithromycin ${ }^{(2)}$. Similarly, Asian countries, to the detect the $\mathrm{T} 2182 \mathrm{C}$ mutation, suggest a lower frequency identification that the mutation A2143G, or yet not associated with resistance to clarithromycin, since the rate in susceptible strains to the clarithromycin is high in China $(86.7 \%)^{(40,113)}$.

Likewise, in Latin American countries, such as Uruguay and Colombia, the $\mathrm{A} 2143 \mathrm{G}$ mutation was the most frequent among strains resistant to clarithromycin ${ }^{(3,100)}$. Several studies have been conducted in the southeast area of Brazil to assess the point mutations in the $23 \mathrm{~S}$ rRNA region, as shown in Table 2. In the city of Belo Horizonte (MG), the A2143G mutation was the most prevalent in a study in which $90.0 \%$ of the isolated resistant strains contained the point mutations $\mathrm{A} 2143 \mathrm{G}$ and/or $\mathrm{A} 2142 \mathrm{G}$ in the $23 S$ rRNA region ${ }^{(52)}$. In São Paulo (SP), studies found that the A2143G mutation was present in $67.0 \%$ and $58.3 \%$ of resistant strains isolated from children and adults respectively who had been prescribed clarithromycin. Both studies, although analyzing strains from patients of different age ranges, analyzed the same number (12) of clinical isolates and also found a lower prevalence of A2142G mutation $(33.0 \% \text { and } 25.0 \%)^{(26,91)}$. Similarly, in northeastern Brazil, the $\mathrm{A} 2143 \mathrm{G}$ point mutation was present in most $H$. pylori isolates $(71.4 \%)$ carrying clarithromycin resistance genotype ${ }^{(49)}$. 
TABLE 2. Antibiotic resistance rate of Helicobacter pylori in Brazil (2000-2012)

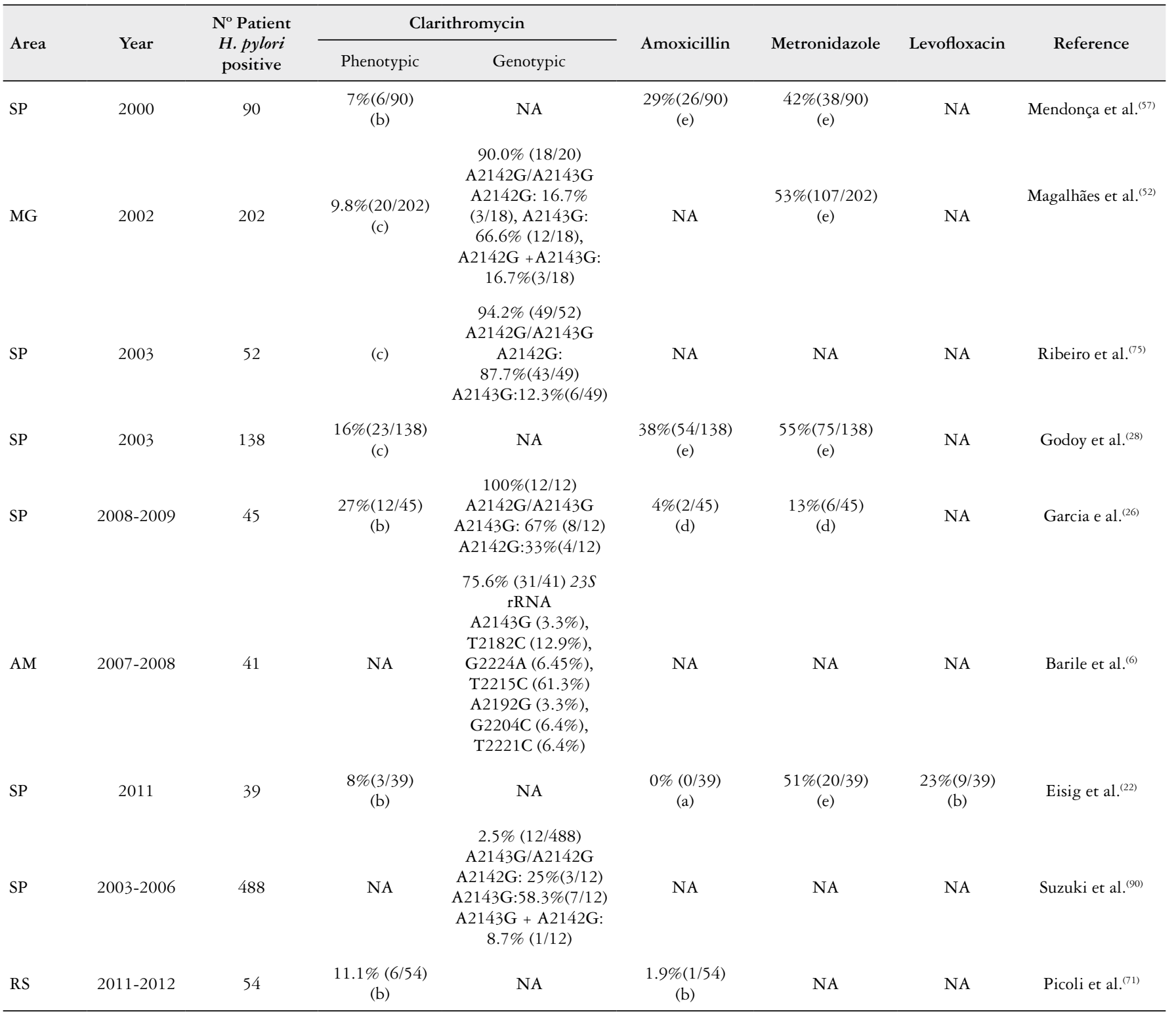

NA: not analized. (a) MIC $\geq 0.5 \mathrm{~g} / \mathrm{mL}$, (b) $\mathrm{MIC} \geq 1 \mu \mathrm{g} / \mathrm{mL}$, (c) $\mathrm{MIC} \geq 2 \mu \mathrm{g} / \mathrm{mL}$, (d) $\mathrm{MIC} \geq 4 \mu \mathrm{g} / \mathrm{mL}$, (e) $\mathrm{MIC} \geq 8 \mu \mathrm{g} / \mathrm{mL}$.

In contrast, in the Amazon, which is located in northern Brazil, Barile et al. (2010) studied the variability of the $23 S$ rRNA gene sequences of 41 isolates from biopsies of patients with gastric pathologies, and identified the A2143G mutation in only $3.3 \%$ of cases, while three other mutations previously linked to cases of resistance were detected in $6.4 \%(\mathrm{G} 2224 \mathrm{~A})$, $12.9 \%$ (T2182C) and $61.3 \%$ (T2215C) of cases. Furthermore, three other types of mutations that are not characterized by any population were found in $16.1 \%$ of cases. In addition to the high prevalence of mutations of the $23 S$ rRNA gene of H. pylori strains circulating in the Amazon (AM), genetic variability of these mutations was detected in individuals with gastric diseases (gastritis, peptic ulcer or gastric cancer), demonstrating the need to regionally characterize the profile of these strains to provide correct therapy ${ }^{(6)}$.

\section{Amoxicillin}

Another drug that is used in combination with standard therapy is amoxicillin, a $\beta$-lactamic antibiotic. This class of drugs binds to the penicillin-binding protein (PBP), enzymes involved in the biosynthesis of the peptidoglycan layer of the bacterial cell wall. Unlike the majority of Gram-negative bacteria that have a major mechanism of resistance through the production of $\beta$-lactamases, $\beta$-lactamic resistance in H. pylori results from changes in PBP that determine one reduced affinity of PBP for $\beta$-lactams ${ }^{(21,67,99)}$. 
Worldwide, the general resistance to amoxicillin is low ${ }^{(69)}$. Studies conducted in both Europe and Africa have not identified amoxicillin resistance in clinical $H$. pylori isolates ${ }^{(7,8,13,82,108)}$. On the other hand, in Latin American countries, such as Chile, Paraguay and Venezuela, the rate of resistance has been found to vary between 0 and $2 \% .(23,29,68)$.

In Brazil, studies that used phenotypic methods also found low rates of resistance to amoxicillin, at $0-4 \%{ }^{(22,26,71)}$. However, as a result of the disproportionate use of these antibiotics, especially for the treatment of common respiratory tract infections, bacteria can develop a tolerance to the drug ${ }^{28,57)}$.

Although research that has examined $H$. pylori isolatesrelated mutations in terms of resistance to amoxicillin are scarce compared to those conducted for clarithromycin, previous studies have shown that the presence of mutations of PBPs is especially linked with PBP1, PBP2, and PBP3 $3^{(21)}$. Studies in Korea and Japan that analyzed the sequence of resistant strains revealed amino acid substitutions in PBP1, including Ser414 $\rightarrow$ Arg and Asn562 $\rightarrow \mathrm{Tyr}^{(41,76)}$. They also showed that mutations in PBP1 and PBP3 provided greater resistance than $\mathrm{PBP} 1$ and $\mathrm{PBP} 2$ mutations, or mutation only in PBP ${ }^{(77)}$. These results demonstrated that amoxicillin resistance in $\mathrm{H}$. pylori is closely associated with amino acid substitutions in the PBP1 region ${ }^{(41,54,67,76)}$.

\section{Metronidazole}

Metronidazole is used as an alternative to clarithromycin and amoxicillin when a patient has an allergy or resistance to these two drugs ${ }^{(18)}$. The mechanism of action of metronidazole involves an oxidation of the bacterial DNA causing disruption of the double helix and consequent cell death ${ }^{(85)}$. H. pylori resistance to metronidazole occurs due to mutations in the gene encoding $r d x A$, a homologue of classical nitroreductase that is responsible for reducing nitroaromatic compounds, such as metronidazole, to a product that is toxic to the bacteria. Thus, resistance is a result of a loss of function by mutational inactivation ${ }^{(30)}$.

In Europe, the primary resistance rates to metronidazole in H. pylori isolates range from $14.0 \%$ to $59.0 \%$ in Italy, Norway, and Poland ${ }^{(7,46,70,80)}$. In Asia and Africa, high rates of resistance have been observed at around $70 \%-85 \%(8,73,82)$. Similarly, developing countries, such as Paraguay (32.6\%), Uruguay $(36.0 \%)$ and Chile $(26.3 \%)$, have higher rates of resistance to metronidazole, and rates in southeastern Brazil are between $40 \%-55 \%(22,23,28,52,57,66,68,100)$. These high rates of resistance may have been result of the frequency of use of metronidazole for the treatment of other infections, such as parasitic and gynecological infections, in these regions, which can result in the development of resistant strains of $H$. pylori $i^{(55)}$.

As mentioned above, the inactivation of the $r d x A$ gene is strongly associated with resistance to metronidazole; however, other resistance mechanisms may exist on this bacterium $^{(36)}$. There are resistant strains that have not show $r d x A$ mutations in the gene, suggesting that other genes that encode a NAD $(\mathrm{P}) \mathrm{H}$ flavin nitroreductase, such as $f r x A$, or mechanisms, such as regulation of transcription of the $r d x A$ gene and the overexpression of $h f A$ efflux pump, could be involved in the generation of resistance ${ }^{(30,36,44,96,101)}$.
According to Jeong et al. (2001), metronidazole resistance development in Canada may be associated with inactivation $r d x A$ or both $r d x A$ and $f r x A^{(37)}$. In Asia, $r d x A$ inactivation was responsible for metronidazole resistance in $66 \%$ of the isolates of $H$. pylori, and the other $33 \%$ were resistant by inactivating both $r d x A$ and $f r x A$. Similar results were found in Malaysia, where rates were $89.1 \%$ for insertions/deletions of $r d x A$ and/or fr $x A$. However, in the same study, $10.8 \%$ of strains resistant to metronidazole exhibited no change in both $r d x A$ and $f r x A$, indicating that mutations in other redox enzymes could be involved in the resistance of the strains; as such, it can be considered that the inactivation of the $r d x A$ gene is often, but not always, associated with the development of metronidazole resistance in $H$. pylori isolates ${ }^{(62,96,98)}$. Therefore, more studies are required to identify the prevalence of metronidazole resistance of this bacterium, and correlating with leading molecular basis of resistance in order to rationally delineate the therapeutic use of this antimicrobial in therapies involving anti-H. pylori.

\section{Levofloxacin}

Fluoroquinolones, such as levofloxacin, are used as an alternative to standard antibiotics to treat $H$. pylori. Many studies suggest that second-line "rescue" therapy for the eradication of $H$. pylori consists of levofloxacin, amoxicillin and an inhibitor of the proton pump. However, the use of levofloxacin should be limited only to "rescue" therapy in order to avoid a rapid increase in $H$. pylori resistance to the quinolone ${ }^{(17,53)}$. The fluoroquinolone mechanism of action operates by inhibiting DNA gyrase and topoisomerase, which control and modify the topological state of DNA in the cell by interfering with bacterial DNA replication. The mechanism of $H$. pylori resistance to the fluoroquinolone appears to be mainly associated with mutations of the gyrA gene, the gene encoding the subunit A of DNA gyrase ${ }^{(27,61)}$.

Resistance ratios of $H$. pylori to this drug have remained constant in Europe, at about $22.0 \%-29.0 \% 0^{(80,110)}$. However, the rates in Asia are more variable and range from 4.9\%$19.5 \%{ }^{(8,89)}$. Furthermore, the primary resistance in Taiwan has increased over time from $4.9 \%$ between 2000 and 2007, to $8.3 \%$ between 2008 and 2010 , and $13.4 \%$ between 2011 and 2012. This has led to calls for new strategies to restrict the consumption of fluoroquinolones ${ }^{(50)}$. In Latin American populations, the summary prevalence was $15 \%$, and an existing study that was conducted in Brazil by Eisig et al. (2011) identified a $23.0 \%$ resistance to levofloxacin ${ }^{(14,22)}$.

Regarding the studies linking $H$. pylori resistance to levofloxacin and the presence of mutations in $g y r A$, can be identified as the main, the changes in Asp91, both in France and in Japan. However, in China, only $37.9 \%$ of the isolates resistant to levofloxacin were associated with Asp91 mutations, while $55.2 \%$ presented Asn $87^{(24,97,106)}$. Thus, it is necessary to estimate the prevalence of levofloxacin and to investigate the molecular basis of levofloxacin resistance through genotypical methods, and to establish a rational use of levofloxacin for the treatment of infections caused by $\mathrm{H}$. pylori. 


\section{FACTORS ASSOCIATED WITH RESISTANCE}

Besides the mechanisms of resistance developed by $H$. pylori to the main antimicrobials used in the treatment of infection of the bacteria, other factors have been associated with resistance, such as the presence or absence of certain pathogenicity genes of bacteria, in addition to the gender and age group of the patients.

Among the pathogenicity genes of $H$. pylori that have been associated with resistance is the cag $A$ gene, which encodes a highly immunogenic protein that can result in varying degrees of inflammatory response ${ }^{(9,10)}$. It has been established that the vacA gene has a mosaic combination of its alleles, which determines the production of the vacuolating cytotoxin $(\operatorname{Vac} A)$ associated with the pathogenicity of the bacterium. In general, the strains of $s 1 / \mathrm{ml} / \mathrm{il}$ produce large amounts of vacuolizing cytotoxin, which is why this genotype seems to be associated with more severe pathologies. In contrast, the strains $s 1 / m 2$ and $s 2 / m 2 / i 2$ show moderate, little, or no cytotoxic activity respectively ${ }^{(4,78,102)}$. This knowledge is important since the presence of virulent genotypes can cause a change in the physiological environment of the stomach, leading to damage to the gastric epithelium and mucus layer, where $H$. pylori resides ${ }^{(103)}$. Therefore, an increase in blood flow can assist in the diffusion of antibiotics that can reach higher concentrations in inflamed mucosa ${ }^{(92)}$.

Studies have shown that strains carrying the $\operatorname{cag} A$ gene are at a higher density and have an intense inflammatory response in the gastric epithelial cells and, thus, can proliferate more rapidly than $\operatorname{cag} A$ negative strains ${ }^{(5,31,105)}$. As antibiotics are most active on the bacteria that grows quickly, $\operatorname{cag} A$-positive strains are more susceptible to antimicrobial activity than negative $\operatorname{cag} A$ strains. Furthermore, cagA negative strains can become resistant by mutation under selective pressure of antimicrobials. Therefore, the absence of $\operatorname{cag} A$ can be a risk factor in the development of antimicrobial resistance ${ }^{(11,92,94)}$.

In order to study the risk ratio for failure and for therapeutic success between $\operatorname{cag} A$-negative and $\operatorname{cag} A$-positive strains, Suzuki et al. (2006), via meta-analysis, found that the presence of the $\operatorname{cag} A$ positive strain increased the likelihood that the treatment of $H$. pylori cag $A$ would be successful by $11 \%$ in comparison to negative strains. Indeed, in the Netherlands, cure rates for $H$. pylori were found to be higher for patients with $H$. pylori cag $A$ positive strains than for those with $\operatorname{cag} A$-negative strains ${ }^{(103)}$.

In addition to the differences in elimination rates between $\operatorname{cag} A$ positive and negative strains, research has found variations between the association of resistance and the presence of $v a c A$ alleles according to their degree of pathogenicity. According to the assessment of the association between $\operatorname{cag} A$ strains and the alleles of $v a c A$, one study in the Netherlands showed that $\operatorname{cag} A+/ v a c A s 1$ strains were more pathogenic and can proliferate faster than cagA-/vacAs 2 strains and, therefore, are more susceptible to antibiotic activity ${ }^{(103)}$. In Spain, H. pylori strains resistant to clarithromycin were also more often associated with the $v a c A s 2 / m 2$ genotype and were more likely to be $\operatorname{cag} A$ negative, indicating that resistance to clarithromycin may be related to less pathogenic clinical isolates ${ }^{(2)}$. However, in Brazil, a significant association between resistance to clarithromycin and vacAs $1 / \mathrm{ml}$ strains was detected ${ }^{(26)}$. This was also detected by Rashed et al. (2014) in Pakistan ${ }^{(73)}$. On the other hand, a study conducted in Italy did not identify any correlation between resistance to clarithromycin and bacterial genomic pattern and/or positivity $\operatorname{cag} A^{(20)}$. As suggested by van Doorn et al. (2000), these data demonstrate the need for studies that evaluate the different $H$. pylori genotypes associated with regionalized antimicrobial resistance profiles, whereas, patterns of pathogenicity factors and association with antibiotic therapy has shown variation among countries ${ }^{(103)}$.

In terms of the association between the presence of resistance to drugs and the gender of patients infected with $H$. pylori, studies have shown that women are more likely to have high rates of drug resistance to the treatments administered as part of $H$. pylori therapy. A significant difference between the genders in terms of clarithromycin resistance was observed in Japan, with a resistance rate of $19.2 \%$ among men compared to $27.0 \%$ among women ${ }^{(43)}$. Accordingly, in Italy, females were found to be at a high risk of developing resistance to clarithromycin and metronidazole. This positive correlation between the resistance to metronidazole and the female gender can be explained by the fact that metronidazole is frequently administered for the treatment of gynecological infections ${ }^{(51,52,109)}$. However, with regard to resistance to levofloxacin, the association was significant with members of the male sex ${ }^{(80)}$.

Studies that have analyzed the relationship between the ages of the patients infected with $H$. pylori have found similar results in terms of resistance to clarithromycin and metronidazole. For both antimicrobials, resistance is more common in children or young adults than it is in older members of the population $^{(2,52)}$. These higher resistance rates in children may be due to the increased prescription of these drugs for respiratory and parasitic infections, which frequently occur in this age group ${ }^{(93)}$. Thus, knowledge of the relationship between these factors and $H$. pylori resistance against antimicrobial agents may confer additional information for the ideal choice of eradication therapy for patients infected with $H$. pylori. However, Zhang et al. (2015) conducted a multivariate analysis that indicated that factors such as gender and age were independent factors in influencing antibiotic resistance ${ }^{(111)}$.

\section{CONCLUSION}

The results of various studies throughout the world that have examined $H$. pylori resistance rates compared to the main drugs used in antimicrobial therapy vary significantly, confirming the hypothesis that antibacterial resistance is a highly local phenomenon. Therefore, it is important to understand the distribution of the levels of specific genes associated with antimicrobial resistance in order to ascertain how the characteristics of a given population can influence which therapy is the most appropriate.

Treatment failure has considerable cost implications/ benefits for the National Health System in terms of drugs, 
diagnostic tests, and medical visits. Therefore, the implementation of incentive policies to reduce the consumption of antibiotics can contribute to a reduction in the levels of resistance to the main antimicrobials used in the anti-H. pylori therapy.

\section{Authors' contributions}

Vianna JS: conducted a literature review, drafting and review of the manuscript. Ramis IB, Ramos DF, Von Groll A and Silva PEA: guidance in the writing and structuring of the manuscript and reviewing the manuscript.

Vianna JS, Ramis IB, Ramos DF, Von Groll A, Silva PEA. A resistência de Helicobacter pylori aos antimicrobianos. Arq Gastroenterol. 2016,53(4):215-23.

RESUMO - Contexto - Helicobacter pylori tem uma distribuição a nível mundial, e está associado a patogênese de várias doenças do sistema digestivo. O tratamento para a erradicação deste microrganismo envolve a utilização de uma combinação de agentes antimicrobianos, tais como amoxicilina, metronidazol, claritromicina e levofloxacino, combinados com inibidores da bomba de prótons. Embora a terapia atual seja eficaz, uma elevada taxa de fracasso de tratamento tem sido observada, principalmente devido à aquisição de mutações pontuais, um dos principais mecanismos de resistência desenvolvida por H. pylori, relacionado com o uso frequente e/ou inadequado dos antibióticos. Conclusão - Esta revisão abordou uma visão geral da resistência às principais drogas utilizadas no tratamento de H. pylori, confirmando a hipótese de que a resistência bacteriana é um fenômeno altamente local e as características genéticas de uma dada população podem influenciar qual terapia é a mais apropriada.

DESCRITORES - Helicobacter pylori. Resistência microbiana a medicamentos. Mutação pontual.

\section{REFERENCES}

1. Abadi AT, Taghvaei T, Ghasemzadeh A, Mobarez AM. High Frequency of A2143G Mutation in Clarithromycin-Resistant Helicobacter pylori Isolates Recovered from Dyspeptic Patients in Iran. J Gastroenterol. 2011;17:396-9.

2. Agudo S, Perez-Perez G, Alarcón T, Lopez-Brea M. High Prevalence of Clarithromycin-Resistant Helicobacter pylori Strains and Risk Factors Associated with Resistance in Madrid, Spain. J Clin Microbiol. 2010;48:3703-7.

3. Alvarez A, Moncayo JI, Santacruz JJ, Santacoloma M, Corredor LF, and Reinosa E. Antimicrobial Susceptibility and Mutations Involved in Clarithromycin Resistance in Helicobacter pylori Isolates from Patients in the Western Central Region of Colombia. Antimicrob Agents Chemother. 2009;53:4022-4.

4. Atherton JC, Cao P, Peek RM, Tummuru MKR, Blaser MJ, and Cover TL. Mosaicism in vacuolating cytotoxin alleles of Helicobacter pylori: association of specific vacA types with cytotoxin production and peptic ulceration. J Biol Chem. 1995;270:17771-7.

5. Atherton JC, Tham KT, Peek RM Jr et al. Density of Helicobacter pylori infection in vivo as assessed by quantitative culture and histology. J. Infect. Dis. 1996; 174:552-6.

6. Barile KAS, Silva ALC, Xavier JNX, Assumpção MB, Corvelo TCO. Characterization of $23 \mathrm{~S}$ rRNA domain $\mathrm{V}$ mutations in gastric biopsy patients from the eastern Amazon. Mem Inst Oswaldo Cruz. 2010;105:314-7.

7. Biernat MM, Poniewierka E, Błaszczuk J, Czapla L, Kempiński R, Ksiądzyna $\mathrm{D}$, et al. Antimicrobial susceptibility of Helicobacter pylori isolates from Lower Silesia, Poland. Arch Med Sci. 2014;10:505-9.

8. Binh TT, Shiota S, Nguyen LT, Ho DDQ, Hoang HH, Ta L, et al. The incidence of primary antibiotic resistance of Helicobacter pylori in Vietnam. J Clin Gastroenterol. 2013;47:233-8.

9. Bittencourt PF, Rocha GA, Penna FJ, Queiroz DM. Gastroduodenal peptic ulcer and Helicobacter pylori infection in children and adolescents. J Pediatr. 2006;82:325-34.

10. Blaser MJ, Berg DE. Helicobacter pylori genetic diversity and risk of human disease. J Clin Invest. 2001;107:767-73.

11. Boyanova L. Prevalence of multidrug-resistant Helicobacter pylori in Bulgaria J Med Microbiol. 2009;58:930-5.

12. Burucoa C, Garnier M, Silvain C, Fauchere JL. Quadruplex real-time PCR assay using allele-specific scorpion primers for detection of mutations conferring clarithromycin resistance to Helicobacter pylori. J Clin Microbiol. 2008;46:2320-6.

13. Cabrita J, Oleastro M, Matos R, Manhente A, Cabral J, Barros R, et al. Features and trends in Helicobacter pylori antibiotic resistance in Lisbon area, Portugal (1990-1999). J Antimicrob Chemother. 2000;46:1029-31.

14. Camargo MC, García A, Riquelme A, Otero W, Camargo CA, Hernandez-García T, et al. The Problem of Helicobacter pylori Resistance to Antibiotics: A Systematic Review in Latin America. Am J Gastroenterol. 2014;109:485-95.

15. Cameron EAB, Bell GD, Baldwin L, Powell KU \& Williams SGJ. Long-term study of re-infection following successful eradication of Helicobacter pylori infection. Aliment Pharmacol Ther. 2006;23:1355-58.

16. Chisholm SA, Owen RJ, Teare EL, Saverymuttu S: PCR-based diagnosis of Helicobacter pylori infection and real-time determination of clarithromycin resistance directly from human gastric biopsy samples. J Clin Microbiol. 2001;39:1217-20
17. Chuah SK, Tai WC, Lee CH, Liang CM, Hu TH. Quinolone-Containing Therapies in the Eradication of Helicobacter pylori. BioMed Research International. 2014.

18. Coelho LG, Maguinilk I, Zaterka S, Parente JM, Passos MCF, Moraes-Filho JPP 3rd Brazilian Consensus on Helicobacter pylori. Arq Gastroenterol. 2013;50(2).

19. Correa P, Piazuelo MB. Natural history of Helicobacter pylori infection. Dig Liver Dis. 2008;40: 490-6.

20. De Francesco V, Margiotta M, Zullo A, Hassan C, Troiane L, Burattini O, et al. Clarithromycin-resistant genotypes and eradication of Helicobacter pylori. Ann Intern Med. 2006;144:94-100.

21. DeLoney CR, Schiller NL. Competition of Various b-Lactam Antibiotics for the Major Penicillin-Binding Proteins of Helicobacter pylori: Antibacterial Activity and Effects on Bacterial Morphology. Antimicrobial Agents and Chemotherapy. 1999;43:2702-9.

22. Eisig JN, Silva FM, Barbuti RC, Navarro-Rodriguez T, Moraes-Filho JP, Pedrazzoli Jr J. Helicobacter pylori antibiotic resistance in Brazil: clarithromycin is stil a good option. Arq Gastroenterol. 2011;48:261-4.

23. Fariña N, Kasamatsu E, Samudio M, Morán M, Sanabria R, Laspina F. Susceptibilidade a antibióticos de cepas paraguayas de Helicobacter pylori aisladas de pacientes com enfermedad gastro-duodenal. Rev Med Chile. 2007:135:1009-14.

24. Fujimura S, Kato S, Iinuma K, Watanabe A. In vitro activity of fluoroquinolone and the gyrA gene mutation in Helicobacter pylori strains isolated from children. Journal of Medical Microbiology. 2004;53:1019-22.

25. Fujimoto S, Marshall B, and Blaser MJ. PCR-based restriction fragment length polymorphism typing of Helicobacter pylori. Ibid. 1994;32:331-4.

26. Garcia GT, Aranda KR, Goncalves ME, Cardoso SR, Iriya K, Silva NP, et al. High prevalence of clarithromycin resistance and $\operatorname{cag} A, \operatorname{vac} A$, ice $A 2$, and babA2 genotypes of Helicobacter pylori in Brazilian children. J Clin Microbiol. 2010;48:4266-8.

27. Garcia M, Raymond J, Garnier M, Cremniter J, Burucoa C. Distribution of Spontaneous gyrA Mutations in 97 Fluoroquinolone- Resistant Helicobacter pylori Isolates Collected in France. Antimicrobial Agents and Chemotherapy. 2012;56:550-1

28. Godoy AP, Ribeiro ML, Benvengo YH, Vitiello L, Miranda Mde C, Mendonca S, et al. Analysis of antimicrobial susceptibility and virulence factors in Helicobacter pylori clinical isolates. BMC Gastroenterol 2003;3:1-6.

29. Gonzalez C, Garcia A, Daroch F, Kawaguchi F, Solar H, Rivera, N, et al. Susceptibilidad in vitro de cepas de Helicobacter pylori: aislamiento de cepas resistentes a claritromicina. Rev. Med. Chile. 2001;129:643-6.

30. Goodwin A, Kersulyte D, Sisson G, Van Zanten SJOV, Berg DE and Hoffman PS. Metronidazole resistance in Helicobacter pylori is due to null mutations in a gene $(r d x A)$ that encodes an oxygen-insensitive NADPH nitroreductase. Molecular Microbiology. 1998;28:383-93.

31. Hamlet A, Thoreson AC, Nilsson O, Svennerholm AM, Olbe L. Duodena Helicobacter pylori infection differs in cag $A$ genotype between asymptomatic subjects and patients with duodenal ulcers. Gastroenterology. 1999;116: 259-68.

32. Hao Q, Li Y, Zhang ZJ, Liu Y, Gao H. New mutation points in 23S rRNA gene associated with Helicobacter pylori resistance to clarithromycin in northeast China. World J Gastroenterol. 2004;10:1075-7. 
33. Hirata k, Suzuki H, Nishizawa T, Tsugawa H Muraoka H, Saito Y, et al. Contribution of efflux pumps to clarithromycin resistance in Helicobacter pylori. $\mathrm{J}$ Gastroenterol Hepatol. 2010;25:75-9.

34. Ierardi E, Giorgio F, Losurdo G, Di Leo, Principi M. How antibiotic resistances could change Helicobacter pylori treatment: A matter of geography? World $\mathbf{J}$ Gastroenterol. 2013;19:8168-80.

35. Jeen YT, Lee SW, Kwon SI, Chun HJ, Lee HS, Song CW et al. Differentiation between reinfection and recrudescence of Helicobacter pylori strains using PCR-based restriction fragment length polymorphism analysis. Yonsei Med J. 2001;42:41-5.

36. Jenks PJ, Ferrero RL, Labgni A. The role of the $r d x A$ gene in the evolution of metronidazole resistance in Helicobacter pylori. J Antimicrob Chemother. 1999;43:753-8.

37. Jeong JY, Mukhopadhyay AK, Akada JK, Dailidiene D, Hoffman PS, Berg DE Roles of FrxA and RdxA Nitroreductases of Helicobacter pylori in Susceptibility and Resistance to Metronidazole. J Bacteriol. 2001;183:5155-62.

38. Jones KR, Cha JH, and Merrel DS. Who's Winning the War? Molecular Mechanisms of Antibiotic Resistance in Helicobacter pylori. Curr Drug ther. 2008:3:190-203.

39. Kawakami E, Machado RS, Ogata SK, Langner M. Decrease in prevalence of Helicobacter pylori infection during a 10-year period in Brazilian children. Arq Gastroenterol. 2008;45:147-51.

40. Kim KS, Kang JO, Eun CS, Han DS, Choi TY. Mutations in the 23S rRNA Gene of Helicobacter pylori Associated with Clarithromycin Resistance. J Korean Med Sci. 2002; 17:599-603

41. Kim MS, Kim N, Kim SE, Jo HJ, Shin CM, Park YS, et al. Long-term follow up Helicobacter pylori reinfection rate after second-line treatment: bismuth-containing quadruple therapy versus moxifloxacin-based triple therapy. BMC Gastroenterology. 2013;13:1-9.

42. Klesiewicz K, Nowak P, Karczewska E, Skiba I, Wojtas- Bonior I, Sito E, et al. PCR-RFLP detection of point mutations A2143G and A2142G in 23S rRNA gene conferring resistance to clarithromycin in Helicobacter pylori strains. Acta Biochima Polonica. 2014;61:311-5.

43. Kobayashi I, Murakami K, Kato M, Kato S, Azuma T, Takahashi S, et al. Changing Antimicrobial Susceptibility Epidemiology of Helicobacter pylori Strains in Japan between 2002 and 2005. J Clin Microbiol. 2007;45:4006-10.

44. Kwon DH, Kim JJ, Lee M, Yamaoka Y, Kato M, Osato MS et al. Isolation and characterization of tetracycline-resistant clinical isolates of Helicobacter pylori. Antimicrob Agents Chemother. 2000;44:3203-5.

45. Kutschke A, Jonge BLM. Compound Efflux in Helicobacter pylori. Antimicrob Agents Chemother. 2005;49:3009-3010.

46. Larsen AL, Ragnhildstveit E, Moayeri B, Eliassen L, Melby KK. Resistance rates of metronidazole and other antibacterials in Helicobacter pylori from previously untreated patients in Norway. APMIS. 2013;121:353-8.

47. Lascols C, Lamarque D, Costa JM, Copie-Bergman C, Le Glaunec JM, Deforges $\mathrm{L}$, et al. Fast and Accurate Quantitative Detection of Helicobacter pylori and Identification of Clarithromycin Resistance Mutations in H. pylori Isolates from Gastric Biopsy Specimens by Real-Time PCR. J Clin Microbiol. 2003;41:4573-7.

48. Li C, Ha T, Chi DS, Ferguson JR DA, Jiang C, Laffan JJ, et al. Differentiation of Helicobacter pylori Strains Directly from Gastric Biopsy Specimens by PCRBased Restriction Fragment Length Polymorphism Analysis without Culture. J Clin Microbiol.1997;35:3021-5.

49. Lins AK, Lima RA, Magalhães M. Clarithromycin-resistant Helicobacter pylori in Recife, Brazil, directly identified from gastric biopsies by polymerase chain reaction. Arq Gastroenterol. 2010;47:379-82.

50. Liou JM, Chang CY, Chen MJ, Chen CC, Fang YJ, Lee JY, W, et al. The Primary Resistance of Helicobacter pylori in Taiwan after the National Policy to Restrict Antibiotic Consumption and Its Relation to Virulence Factors-A Nationwide Study. PLoS One. 2015;10.

51. Liou JM, Chang CY, Sheng WH, WangYC, Chen MJ, LeeYC, et al. Genotypic Resistance in Helicobacter pylori Strains Correlates with Susceptibility Test and Treatment Outcomes after Levofloxacin and Clarithromycin-Based Therapies. Antimicrob Agents Chemother. 2011;55:1123-9.

52. Magalhães PP, Queiroz DM, Barbosa DV, Rocha GA, Mendes EN, Santos A, et al. Helicobacter pylori primary resistance to metronidazole and clarithromycin in Brazil. Antimicrob Agents Chemother. 2002;46:2021-3.

53. Malfertheiner P, Megraud F, O'Morain CA, Atherton J, Axon AT, Bazzoli F, et al. Management of Helicobacter pylori infection--the Maastricht $\mathbb{Q}$ / Florence Consensus Report. Gut. 2012;61:646-64.

54. Matteo MJ, Granados G, Olmos M, Wonaga AS, Catalano M. Helicobacter pylori amoxicillin heteroresistance due to point mutations in PBP-1A in isogenic isolates. J Antimicrob Chemother. 2008;61:474-7.

55. Megraud F and Lehours P. Helicobacter pylori Detection and Antimicrobial Susceptibility Testing. Clinical Microbiology Reviews. 2007;20:280-322.
56. Ménard A, Santos A, Mégraud F, Oleastro M. PCR-restriction fragment length polymorphism can also detect point mutation A2142C in the 23S rRNA gene, associated with Helicobacter pylori resistance to clarithromycin. Antimicrob Agents Chemother. 2002;46:1156-7.

57. Mendonça S, Ecclissato C, Sartori MS, Godoy AP, Guerzoni RA, Degger M, et al. Prevalence of Helicobacter pylori resistance to metronidazole, clarithromycin, amoxicillin, tetracycline, and furazolidone in Brazil. Helicobacter. 2000;5:79-83.

58. Menninger JR. Functional consequences of binding macrolides to ribosomes. J Antimicrob Chemother. 1985;23-34.

59. Menoni SMF, Bonon SHA, Zeitune JMR and Costa SCB. PCR-Based Detection and Genotyping of Helicobacter pylori in Endoscopic Biopsy Samples from Brazilian Patients. Gastroenterology Research and Practice. 2013.

60. Miendje Deyi VY, Vanderpas J, Bontems P, Van den Borre C, De Koster E, Cadranel S, et al. Marching cohort of Helicobacter pylori infection over two decades (1988-2007): combined effects of secular trend and population migration. Epidemiol Infect. 2011;139:572-80.

61. Miyachi H, Miki I, Aoyama N, Shirasaka D, Matsumoto Y, Toyoda M, et al. Primary levofloxacin resistance and gyrA/B mutations among Helicobacter pylori in Japan. Helicobacter. 2006;11:243-9.

62. Nahar S, Mukhopadhyay AK, Khan R, Ahmad MM, Datta SS, Chattopadhyay SS, et al. Antimicrobial Susceptibility of Helicobacter pylori Strains Isolated in Bangladesh. J Clinical Microbiol. 2004,42:4856-8.

63. Navabakbar F, Salehi R. PCR and RFLP Analysis for Identification and Typing of Helicobacter pylori Strains from Gastric Biopsy Specimens. Journal of Sciences, Islamic Republic of Iran. 2004;15:227-31.

64. Nikaido H. Multidrug Efflux Pumps of Gram-Negative Bacteria. J Bacteriol. 1996; 178:5853-9.

65. Occhialini A, Urdaci M, Doucet-Populaire F, Bebear CM, Lamouliatte H, Megraud F. Macrolide resistance in Helicobacter pylori: rapid detection of point mutation and assays of macrolide binding to ribosomes. Antimicrob Agents Chemother. 1997;41:2724-8.

66. Ogata SK, Godoy AP, da Silva Patricio FR, Kawakami E. High Helicobacter pylori resistance to metronidazole and clarithromycin in Brazilian children and adolescents. J Pediatr Gastroenterol Nutr. 2013;56:645-8.

67. Okamoto T, Yoshiyama H, Nakazawa T, Park ID, Chang MW, Yanai H, et al. 2002. A change in PBP1 is involved in amoxicillin resistance of clinical isolates of Helicobacter pylori. Chemotherapy. 2002;50:849-56.

68. Otth L, Wilson M, Fernández H, Otth C, Toledo C, Cárcamo V, et al. Isolation of Helicobacter pylori in gastric mucosa and susceptibility to five antimicrobial drugs in Southern Chile. Braz J Microbiol. 2011;42:442-7.

69. Pajares-García JM, Pajares-Villarroya R, Gisbert JP. Helicobacter pylori infection: antibiotic resistance. Rev Esp Enferm Dig. 2007;99:63-70.

70. Perri F,Villani MR, Festa V, Quitadamo M, Andriulli A. Predictors of failure of Helicobacter pylori eradication with the standard 'Maastricht triple therapy'. Aliment Pharmacol Ther. 2001;15:1023-9.

71. Picoli SU, Mazzoleni LE, Fernández H, DE Bona LR, Neuhauss E, Longo L \&Prolla JC. Resistance to amoxicillin, clarithromycin and ciprofloxacin of Helicobacter pylori isolated from southern Brazil patients. Rev. Inst. Med. Trop. Sao Paul. 2014;56:197-200.

72. Ramis IB, de Moraes EP, Fernandes MS, Mendoza-Sassi R, Rodrigues O, Juliano $\mathrm{CR}$, et al. Evaluation of diagnostic methods for the detection of Helicobacter pylori in gastric biopsy specimens of dyspeptic patients. Braz J Microbiol. 2012;43:903-8.

73. Rasheed F, Campbell BJ, Alfizah H, Varro A, Zahra R, Yamaoka Y, et al. Analysis of Clinical Isolates of Helicobacter pylori in Pakistan Reveals High Degrees of Pathogenicity and High Frequencies of Antibiotic Resistance. Helicobacter. 2014;19:387-99.

74. Raymond J, Burucoa C, Pietrini O, Bergeret M, Decoster A, Wann A, et al. Clarithromycin resistance in Helicobacter pylori strains isolated from French children: prevalence of the different mutations and coexistence of clones harboring two different mutations in the same biopsy. Helicobacter. 2007;12:157-63.

75. Ribeiro ML, Vitiello L, Miranda MCB, Benvengo YH, Godoy APO, Mendonca $\mathrm{S}$, et al. Mutations in the 23S rRNA gene are associated with clarithromycin resistance in Helicobacter pylori isolates in Brazil. Ann Clin Microbiol Antimicrob. 2003;2:1-4.

76. Rimbara E, Noguchi N, Kawai T, Sasatsu M. Correlation between substitutions in penicillin-binding protein 1 and amoxicillin resistance in Helicobacter pylori. Microbiol Immunol 2007;51:939-44.

77. Rimbara E, Noguchi N, Kawai T, Sasatsu M. Novel mutation in 23S rRNA that confers low-level resistance to clarithromycin in Helicobacter pylori. Antimicrob Agents Chemother. 2008;52:3465-6.

78. Rhead JL, Letley DP, Mohammadi M, Hussein N, Mohagheghi MA, Eshagh Hosseini M, et al. A new Helicobacter pylori vacuolating cytotoxin determinant, the intermediate region, is associated with gastric cancer. Gastroenterology. 2007;133:926-36. 
79. Rongli C, Liya Z. Helicobacter pylori infection: an overview in 2013, focus on therapy. Chin Med J. 2014;127:568-73.

80. Saracino IM, Zullo A, Holton J, Castelli V, Fiorini G, Zaccaro C, et al. High prevalence of primary antibiotic resistance in Helicobacter pylori isolates in Italy. J Gastrointestin Liver Dis. 2012;21:363-5.

81. Sasaki M, Ogasawara N, Utsumi K, Kawamura N, Kamiya T, Kataoka H, et al. Changes inel12-cYear Firstt-iLine Eradication Rate of Helicobacter pylori Based on Triple Therapy with Proton Pump Inhibitor, Amoxicillin and Clarithromycin. J Clin Biochem Nutr. 2010;47:53-8.

82. Seck A, Burucoa C, Dia D, Mbengue M, Onambele M, Raymond J, et al. Primary antibiotic resistance and associated mechanisms in Helicobacter pylori isolates from Senegalese patients. Ann Clin Microbiol Antimicrob. 2013;12:1-5.

83. Selgrad M, Meissle J, Bornschein J, Kandulski A, Langner C, Varbanova M, et al. Antibiotic susceptibility of Helicobacter pylori in central Germany and its relationship with the number of eradication therapies. Eur J Gastroenterol Hepatol. 2013;25:1257-60.

84. Sierra F, Forero JD, Rey M. Tratamiento ideal del Helicobacter pylori: una revisión sistemática. Revista de Gastroenterología de México. 2014;79:28-49.

85. Sisson G, Jeong J-Y, Goodwin A, Bryden L, Rossler N, Lim-Morrison S et al. Metronidazole activation is mutagenic and causes DNA fragmentation in Helicobacter pylori and in Escherichia coli containing a cloned $H$. pylori $r d x A+$ (nitroreductase) gene. J Bacteriol. 2001;182:5091-6.

86. Song HJ, Chung IS, Kim SW, Lee GM, Kim BW, Lee DS, et al. Antimicrobial resistance rates in Helicobacter pylori and detection of $23 \mathrm{~s}$ rRNA mutation associated with claritromycin resistance. Korean J Gastroenterol. 2000;36:597-606.

87. Stone GG, Shortridge D, Flamm RK, Beyer J, Ghineim AT, Tanaka SK PCR-RFLP typing of ureC from Helicobacter pylori isolated from gastric biopsies during a European multi-country clinical trial. J Antimicrob Chemother 1997a;40:251-6.

88. Stone GG, Shortridge D, Flamm RK, Beyer J, Stamler D, Tanaka SK. PCRRFLP typing of ureC from Helicobacter pylori isolated in Argentina from gastric biopsies before and after treatment with clarithromycin. Epidemiol Infect. 1997b;118:119-24

89. Su P, Li Y, Li H, Zhang J, Lin L, Wang Q, et al. Antibiotic resistance of Helicobacter pylori isolated in the Southeast Coastal Region of China. Helicobacter. 2013;18:274-9.

90. Suzuki RB, Almeida CM, Speranca MA: Absence of Helicobacter pylori high tetracycline resistant 16S rDNA AGA926-928TTC genotype in gastric biopsy specimens from dyspeptic patients of a city in the interior of Sao Paulo, Brazil. BMC Gastroenterol. 2012;12:1-5.

91. Suzuki RB, Lopes RAB, George Lopes AC, Ho TH and Sperança MA. Low Helicobacter pylori primary resistance to clarithromycin in gastric biopsy specimens from dyspeptic patients of a city in the interior of São Paulo, Brazil. BMC Gastroenterology. 2013;13:1-7.

92. Suzuki T, Matsuo K, Sawaki A, Ito H, Hirosek, Wakai K, et al. Systematic review and meta-analysis: importance of $\mathrm{Cag} A$ status for successful eradication of Helicobacter pylori infection. Aliment Pharmacol Ther. 2006;24:273-80.

93. Taneike I, Goshi S, Tamura Y, Wakisaka-Saito N, Matsumori N, Yanase A, et al. Emergence of Clarithromycin-Resistant Helicobacter pylori (CRHP) with a High Prevalence in Children Compared with Their Parents. Helicobacter. 2002;7:297-305

94. Taneike I, Nami A, O'Connor A, Fitzgerald N, Murphy P, Qasim A, et al. Analysis of drug resistance and virulence-factor genotype of Irish Helicobacter pylori strains: is there any relationship between resistance to metronidazole and cag $\mathrm{A}$ status? Aliment Pharmacol Ther. 2009;30:784-90.

95. Tanih NF and Ndip RN. Molecular Detection of Antibiotic Resistance in South African Isolates of Helicobacter pylori. Gastroenterology Research and Practice. 2013; Article ID:259457.
96. Tankovic J, Lamarque D, Delchier JC, Soussy CJ, Labigne A, Jenks PJ. Frequent Association between Alteration of the $r d x A$ Gene and Metronidazole Resistance in French and North African Isolates of Helicobacter pylori. Antimicrobial agents and chemotherapy. 2000;44:608-13.

97. Tankovic J, Lascols C, Sculo Q, Petit JC, Soussy CJ Single and Double Mutations in gyrA but Not in gyrB are Associated with Low- and High-Leve Fluoroquinolone Resistance in Helicobacter pylori. Antimicrobial Agents and Chemotherapy. 2003;47:3942-4.

98. The X, Khosravi Y, Ching Lee W, Leow AHR, Loke MF, Vadivelu J, et al. Functional and Molecular Surveillance of Helicobacter pylori Antibiotic Resistance in Kuala Lumpur. PLOS ONE. 2014;9:1-8.

99. Therrien C, Levesque RC. Molecular basis of antibiotic resistance and beta-lactamase inhibition by mechanism based inactivators: perspectives and future directions. FEMS Microbiology Reviews. 2000;24:251-62.

100. Torres-Debat ME, Perez-Perez G, Olivares A, Fernandez L, Raisler K, Gonzalez N, et al. Antimicrobial susceptibility of Helicobacter pylori and mechanisms of clarithromycin resistance in strains isolated from patients in Uruguay. Rev Esp Enferm Dig. 2009;101:757-62.

101. Tsugawa H, Suzuki H, Muraoka H, Ikeda F, Hirata K, Matsuzaki J, et al. Enhanced bacterial efflux system is the first step to the development of metronidazole resistance in Helicobacter pylori. Biochemical and Biophysical Research Communications. 2011;404:656-60.

102. van Doorn LJ, Figueiredo C, Sanna R, et al. Expanding allelic diversity of Helicobacter pylori vacA. J Clin Microbiol. 1998;36:2597-603.

103. van Doorn LJ, Schneeberger PM, Nouhan N, Plaisier AP, Quint WGV, Boer WA. Importance of Helicobacter pylori cag $A$ and $v a c A$ status for the efficacy of antibiotic treatment. Gut. 2000;46:321-6.

104. Versalovic J, Osato MS, Spakovsky K, Dore MP, Reddy R, Stone GG, et al. Point mutations in the 23S rRNA gene of Helicobacter pylori associated with different levels of clarithromycin resistance. J Antimicrob Chemother. 1997;40:283-6.

105. Vilaichone RK, Mahachai V, Tumwasorn S, Wu JY, Graham DY, Yamaoka Y. Gastric mucosal cytokine levels in relation to host interleukin-1 polymorphisms and Helicobacter pylori cagA genotype. Scand. J. Gastroenterol. 2005;40:530-9.

106. Wang LH, Cheng H, Hu FL, Li J. Distribution of gyrA mutations in fluoroquinolone-resistant Helicobacter pylori strains. World J Gastroenterol. 2010;16:2272-7.

107. Warren JR, Marshall BJ. Unidentified curved bacilli on gastric ephitelium in active chronic gastritis. Lancet. 1983;321:1273-5.

108. Wolle K, Leodolter A, Malfertheiner P, König W. Antibiotic susceptibility of Helicobacter pylori in Germany: stable primary resistance from 1995 to 2000 J Med Microbiol. 2002;51:705-9.

109. Wu DC, Hsu PI, Wu JY, Opekun AR, Kuo CH, Wu IC, et al Sequential and Concomitant Therapy with 4 drugs are Equally Effective for Eradication of H. pylori Infection. Clin Gastroenterol Hepatol. 2010;8:36-41.

110. Wueppenhorst N, Stueger HP, Kist M, Glocker EO. High secondary resistance to quinolones in German Helicobacter pylori clinical isolates. J Antimicrob Chemother. 2013;68:1562-6.

111. Zhang YX, Zhou LY, Song ZQ, Zhang JZ, He LH, Ding Y. Primary antibiotic resistance of Helicobacter pylori strains isolated from patients with dyspeptic symptoms in Beijing: A prospective serial study. World J Gastroenterol. 2015;21:2786-92.

112. Zhao LJ, Huang YQ, Chen BP, Mo XQ, Huang ZS, Huang XF, et al. Helicobacter pylori isolates from ethnic minority patients in Guangxi: Resistance rates, mechanisms, and genotype. World J Gastroenterol. 2014;20:4761-70.

113. Zhen-Hua Z, De-Qiang H, Yong X, Lin-Lin L, Nong-Hua L. Characterization of 23S rRNA gene mutation in primary and secondary clarithromycin-resistant Helicobacter pylori strains from East China. Turk J Gastroenterol. 2013;24:5-9. 